\title{
Animal performance and economic implications of Holstein-Friesian, Jersey and Jersey $\times$ Holstein-Friesian cows under seasonal pasture based systems
}

\author{
R. Prendiville ${ }^{1,2}$, L. Shalloo ${ }^{1}$, K.M. Pierce ${ }^{2}$, F. Buckley $^{1}$
}

${ }^{1}$ Teagasc, Moorepark, Dairy Production Research Centre, Fermoy, Co. Cork, Ireland

${ }^{2}$ School of Agriculture, Food Science and Veterinary Medicine, UCD, Belfield, Dublin 4, Ireland

Email: robert.prendiville@teagasc.ie

Introduction In seasonal production systems such as Ireland the aim is to optimise milk production from pasture with limited concentrate supplementation. Ideally cows in such systems should efficiently convert pasture to product and maintain a calving interval around 365 days. Crossbreeding, particularly with the Jersey (J), is common practice in New Zealand and Lopez-Villalobos et al. (2000) reported Jersey $\times$ Holstein-Friesian $\left(\mathrm{F}_{1}\right)$ cows to be more profitable than the parent breeds. The J breed would appear to offer potential for crossbreeding under Irish conditions with its small size, the prospect of improved reproductive performance, and high milk components which with the introduction of multi component price systems of payment is of particular interest in adding value to milk (Shalloo, 2007). The aim of this study was to provide comparative cow performance data and the implications of same for overall farm profitability of HolsteinFriesian (HF), $\mathrm{J}$ and $\mathrm{F}_{1}$ cows under Irish seasonal pasture-based management.

Material and methods A total of 329 lactations from $65 \mathrm{HF}, 48 \mathrm{~J}$ and $49 \mathrm{~F}_{1}$ cows were available from a three year study; 2006, 2007 and 2008 (years 1, 2 and 3, respectively), conducted at the 'Ballydague' research farm. Cows were managed in a seasonal production system (Dillon et al., 1995). Milk yield was recorded daily while milk components and bodyweight were determined weekly. A more detailed description of fertility measures is provided by Prendiville et al. (2010). The Moorepark Dairy Systems Model (MDSM) (Shalloo et al., 2004), a stochastic budgetary simulation model was used to simulate a model farm integrating biological data for each breed group. This model incorporates animal inventory and valuation, milk production, feed requirement, land, labour and economic analysis. Variable costs including fertilizer, contractor charges, medical and veterinarian, artificial insemination, silage and reseeding, fixed costs (machinery maintenance and running costs, farm maintenance, car, telephone, electricity and insurance) and sales values (milk, cull cow and calf) were included at current prices (Teagasc, 2008). The model was limited to 40 hectare of land and $13 \mathrm{t}$ DM of grass/ha was assumed to be grown. Fertilizer application was assumed to be $250 \mathrm{~kg}$ of N/ha. A milk price of $27 \mathrm{c} / 1$ at $33.0 \mathrm{~g} / \mathrm{kg}$ protein and $36.0 \mathrm{~g} / \mathrm{kg}$ fat with a ratio of the value of protein to fat of 2.6 to 1 was used. Cull cow price was assumed to be $€ 366, € 149$ and $€ 268$ for the $\mathrm{HF}, \mathrm{J}$ and $\mathrm{F}_{1}$, respectively (for details see Prendiville et al., 2010). All calves were assumed sold at 4 weeks of age. Male calf value was $€ 80, € 0$ and $€ 30$ for $\mathrm{HF}, \mathrm{J}$ and $\mathrm{F}_{1}$, respectively, while female calves were valued at $€ 330$. Replacement rate was calculated as the proportion of cows that failed to become pregnant by the end of the 13-week breeding season plus a voluntary culling rate of $10 \%$ of the remaining cows. Fertility values obtained for the HF and J were not statistically different. Consequently, empty rates were $18 \%$ for the HF and J and $9 \%$ for the $F_{1}$. Due to the differences in replacement rates milk yield was adjusted for parity structure. Differences in calving date were also assumed based on differences in calving to conception interval.

Results According to the model $96 \mathrm{HF}, 114 \mathrm{~J}$ and $97 \mathrm{~F}_{1}$ cows would be facilitated on the 40 ha land base. Milk yield was highest with the $\mathrm{HF}(5,651 \mathrm{~kg})$, intermediate with the $\mathrm{F}_{1}(5,272 \mathrm{~kg})$ and lowest with the $\mathrm{J}(4,220 \mathrm{~kg})$. Milk fat and protein content were highest for the $\mathrm{J}(5.32 \%$ and $4.03 \%)$, intermediate with the $\mathrm{F}_{1}(4.77 \%$ and $3.88 \%)$ and lowest with $\mathrm{HF}(4.12 \%$ and 3.49\%). Consequently, milk solids production was highest for the $F_{1}(456 \mathrm{~kg})$ intermediate for the $\mathrm{HF}$ (430kg) and lowest for the $J(395 \mathrm{~kg})$. Milk returns were highest for the $J(€ 172,816)$, intermediate for the $F_{1}(€ 171,790)$ and lowest with the HF $(€ 158,675)$. Due to additional animal numbers labour cost was higher with the $J(€ 32,811)$ compared to the HF and $F_{1}\left(€ 27,760\right.$ and $€ 28,463$, respectively). Replacement costs were lowest with the $F_{1}(€ 26,935)$, intermediate with the HF $(€ 38,904)$ and highest with the $J(€ 45,982)$. Livestock sales were highest for the HF $(€ 28,675)$ and similar for the $J$ and $F_{1}$ ( $€ 22,696$ and $€ 21,674$ ). Total costs were $€ 149,852, € 167,089$ and $€ 137,786$ for the HF, $J$ and $F_{1}$, respectively. However, overall farm profit was highest with the $F_{1}(€ 55,678)$ followed by the HF $(€ 37,499)$ and $J(€ 28,423)$. Farm profitability per hectare was highest for the $F_{1}(€ 1,392)$, intermediate for the HF (€938) and lowest for the $J(€ 711)$. The additional profit generated by the $F_{1}$ is largely attributed to increased milk value and lower replacement costs i.e. improved reproductive efficiency.

Conclusions In Ireland the impending removal of EU milk quotas will result in land becoming the most limiting resource. Although many farmers view crossbreeding as a means of improving reproductive performance and herd health, results from this study indicate that despite the lower livestock sales (cull cow and calf revenue), overall farm profitability with $\mathrm{F}_{1}$ cows may well be higher compared to HF cows, due to greater milk receipts coupled with improved reproductive efficiency and survival.

Acknowledgements Financial support from the Research Stimulus Fund (RSF-06-353) is gratefully acknowledged.

\section{References}

Dillon, P., Crosse, S., Stakelum, G. and Flynn, F. 1995. Grass Forage Science 50, 286-299.

Lopez-Villalobos N., Garrick, D.J., Holmes, C.W., Blair, H.T. and Spelman, R.J. 2000. Journal of Dairy Science 83, 144153.

Prendiville R. 2010. PhD. Thesis, National University of Ireland, Dublin, Ireland.

Shalloo L., Dillon, P., Rath, M. and Wallace, M. 2004. Journal of Dairy Science 87, 1945-1959.

Teagasc. 2008. Management data for farm planning. Teagasc, Oakpark, Carlow, Ireland. 